\title{
Harmony between Chinese and Balinese Ethnics in Bali
}

\author{
I Gusti Made Aryana \\ History Department \\ Universitas Pendidikan Ganesha \\ Singaraja, Indonesia \\ gustimadearyana@ymail.com
}

\begin{abstract}
This article analyzed the harmonious relations between Chinese and Balinese ethnics in Pupuan Village, Tabanan, Bali by relating the existence of the other ethnicity with the local wisdom based on the ideology of Tri Hita Karana. The data were collected through in-depth interview, observation, and documents study and were analyzed by interactive analysis model using critical social theory. The study revealed that the harmony between the two ethnicities was strongly influenced by the Tri Hita Karana concept actualized through equal social relationship, acculturation, and assimilation. Although the possibility of conflict between ethnic and religion happened, the social interaction between the two ethnics showed the cultural endurance that can be used as a prototype of diversity in Indonesia in the degradation of national values.
\end{abstract}

Keywords: Ethnicity, Harmony, Local Wisdom, Tri Hita Karana.

\section{INTRODUCTION}

Pupuan village is one of the old villages in Pupuan district, Tabanan, Bali. Demographically, the village has 3.265 in population with 851 families and this includes 113 Chinese [1]. Although the Chinese ethnic is a minority group, the relation between the two ethnics is harmonious. The Chinese ethnics in this village have done amalgamation marriage, which is not common in endogamy practice among the general Chinese [2]. In addition, they also do ceremonies like what Balinese ethnics do. They also have shrines which look like Hindus, such as sanggah kemulan, pelinggih Jro Gede, and Taksu. They also become members of "Desa Pakraman" in Pupuan village.

This harmonious relation was very paradoxical compared to what happened outside Bali. In some cases, Chinese ethnics got discrimination treatment which ended with physical violence [3]. This paradoxical phenomenon inspired the scholars to investigate, especially in the form of research on the Chinese ethnics in Pupuan village which still scare [4]. Today this research became important and interesting to be done since there was a symptom of national disintegration and the delicate nature of the nation's unity, which became a national issue. Moreover, this research is really important by seeing the schools where the research had been done showed that the interaction among them was very harmony. This condition should be spread out through the education system. The study of the harmonious interrelation in Pupuan was done with the focus on why the Chinese and Balinese ethnics can live side by side harmoniously.

\section{Review of Literature}

A study on Chinese ethnics with various problems they faced as Diasporas ethnic in various regions in general and in Indonesia in particular have been done by many scholars, especially in the economic areas in which they worked as merchants in urban industries [5]. Meanwhile, studies of Chinese ethnics in villages are still rare. In Bali, there were a few studies on Chinese ethnics such as [6], [7]. In addition, there were also some scholars who investigated Chinese ethnics outside Bali such as [8], [9], and [10].

The research from Griya intensively described the meaningful contribution and synergy for the dynamics of local, national as well as universal cultures civilizations [6]. The method used was descriptive qualitative method using anthropological analysis. Substantively, Griya held the opinion that the interrelation between Chinese and Balinese in Bali was extensive and intensive based on the principles of reciprocity, acculturation and tolerance. It is also explained in this work that the parallel and similar characteristics have encouraged the integration of the two ethnics in cultural aspect.

In book entitled "Dari Tatapan Mata ke Pelaminan Sampai di Desa Pakraman: Studi tentang Hubungan Orang Bali dengan Orang Cina di Bali" discussed the harmonious relation between Chinese ethnics in three locations, namely: Baturiti village, Carangsari village and Padangbai village [7]. This study is different from the present study in its aim and study location although both study the existence of Chinese ethnics. Apart from this, the study gave insights to the writer in understanding deeply in the multicultural life and interethnic marriages as well as their implications in interactions in the field.

Charles A. Coppel in his book entitled "Tionghoa Indonesia Dalam Krisis" discussed the historical background of Chinese ethnic's problems and how the problems were developed and how Chinese ethnic communities in Indonesia accommodate themselves with the difficulties of the national politics [8]. In addition, it also looks at some other things about Indonesian Chinese who were the prisoners of their 
ethnic past history. According to his book, as a minority ethnic group, but a relatively rich group through unbalanced trading activities, they caused antipathy from their Indonesian competitors. Chinese are very influential in economic sector and often have agreements with the rulers. However, when anti-Chinese prejudice broke out and when a conflict of interest continued then there will be a dilemma in which if they are too intimate with the rulers that can bring about a danger for themselves when the government fell.

Coppel's work was comprehensive and it was about the emergence of some problems of the Chinese ethnics (the Chinese ethnic crisis) in Indonesia. His approach employed temporal (historical) approach, since the presence of the descendents of Chinese ethnic immigrants who spread over Indonesia (Diaspora). How the rulers have treated the Chinese ethnics since the colonial time until the post-independence period was also the subject of discussion in this work. The exposition was very different from the present study, since this present study is limited in locality and substance. However, Coppel's work was very useful for the writer, in tracing the dynamics of the life of the Chinese ethnics in Pupuan village, which was also not free from the policies to which they have been subjected since their arrival at Pupuan village, both in the pre-colonial era (kingdom era) and the post-independence era.

Poerwanto in his book entitled "Orang Cina Khek dari Singkawang" discussed the proposal of assimilation to overcome the Chinese ethnic problems in Indonesia, the history of Chinese ethnics in Indonesia, the relation to national assimilation and integration, the migration of the Chinese ethnics to Kalimantan since the colonial era, and the assimilation of the Chinese ethnics in Singkawang [9]. Poerwanto's work has a very clear focus in Kalimantan about the life and the history of the presence of the Chinese ethnics in Singkawang as well as the proposal made to overcome the problems of the Chinese ethics in Indonesia through assimilation.

Different from that, this study was substantively limited to the locality aspect, in which it was done only in a village in the hinterland, that is, Pupuan village. However, Poerwanto's work helped the writer very much especially in relation to the historical tracing of the presence of the Chinese ethnics in Pupuan village especially it cannot be separated from the presence of Chinese ethnics in Indonesia in general.

Jemma Purdey in his book entitled "Kekerasan Anti Tionghoa di Indonesia 1996-1999" discussed the relation between Indonesian and Chinese, the minority in the middle, the spreading of dissatisfaction, the increase of anti-Chinese sentiment, climax, representing and remembering, and the change of regime and transition [10]. Purdey's work was of course different from the that the writer did, since Purdey focused more on violence suffered by Chinese ethnics done by the non-Chinese ethnics, was a reflection of disharmony, while the present study discusses an interethnic harmony between Chinese and Balinese in Pupuan village up to the time this work was conducted.

In addition to the works mentioned there are still many monumental works from scholars that discussed the presence of Chinese ethnics in Indonesia and overseas with all of the problems faced by them in foreign lands, such as [11], [12], [13], [14], [15], [16], [17]. However, the results of library search proved that there has no research discussed the subject using critical ethnography to see the relation between two different ethnics but form the relation developed a harmony. Although some works touched on and selected the same location, the studies were very positivistic and the background or the formulation of the problems was different. In addition, from the library search, it was found that there was no further discussion on the development of a harmonious relation between two ethnics with different cultural backgrounds in Pupuan village, which used cultural studies and critical ethnographical approach. This research is important to be done and the result can be used to support the character education that was being done by the government to help in succeeding the Revolusi Mental programmed and also to create a harmonious live in the plural civilization.

\section{METHOD}

This study used descriptive qualitative method with critical ethnographic approach in the Cultural Studies perspective [18]. The data were collected through in-depth interview with public figures from the two ethnics in Pupuan whom were regarded knowledgeable about the problems being studied, which included head of Pupuan village, Bendesa Adat (traditional custom leader) of Pupuan, chairman of Karang Semadhi Organization from the Chinese ethnics, chairman of Sekaa Truna-Truni (Balinese youth organization), and public figures. Direct observation was made to Pupuan village environment, the shrines of the two ethnics in Pupuan village, ceremonies, and other social activities that took place in the location of study. Meanwhile, the document's study was done by finding sources like monograph and profile of Pupuan village, and other documents in various places to strengthen the data needed. After the data were collected, they were analyzed using interactive analysis model [19] with the help from critical theory to produce a critical ethnography.

Some grand theories used were Bourdieu Practice Theory [20], [21], [22], [23], [24] which in principle said that there was capital games (economic, social, cultural, and symbolic) which also caused the development of a harmonious life. Therefore, Bourdieu's theory is important to analyzed data which were related to the reasons of why the Chinese ethnics and the local community of Pupuan can live side by side in harmony. Meanwhile, Foucault's Power/Knowledge Discourse [25], [26] in general pinpointed that power is everywhere and those who have knowledge, have power. On the basis of this theory, in relation to Pupuan village there was a power game, which caused the dynamics in the interaction of the two ethnics. Thus, Foucault's theory was also useful for analyzing data on the development of dynamics in the relation between both ethnics in Pupuan. Jurgen Habermas's theory stressed the importance of a communication to settle various problems by negotiation and dialogue by agents/actors among the interest parties to find consensus [27]. Beside these main 
theories, other theories were also used such as Gramci's hegemony theory, which was also relevant and this theory was used eclectically [28]. Furthermore, the result of the data analysis which was presented descriptive-qualitatively with inductive model as the distinctive feature of Cultural Studies and was supplemented with the explanative power or critical argumentative power of Critical Social Theory.

\section{RESULT AND DISCUSSION}

Harmonious culture between Chinese and Balinese ethnics in Pupuan village, the results showed that there were various reasons that caused Chinese ethnics and Balinese ethnics in Pupuan village can live side by side in harmony. The reasons were the presence of power game and capital game played by Balinese ethnics and Chinese ethnics so that both conformed to or obey the regulations contained in Tri Hita Karana (THK), which was used as the guide to be done by all the local community members (krama) in such a way that the member felt that they were being protected and oriented toward a harmony. Similarly, the two ethnics used social capital by developing and maintaining local wisdom values about fraternity (penyamabrayaan) which was used as the pillar to actualize the sense of belonging, respect, tolerance that were oriented toward the development of a harmonious relation.

Social and symbolic capital game between them caused an increasingly matured and more strongly protected fraternity, through, intermarriage (amalgamation) in Pupuan village to develop an increasingly intimate tie (in groupness) and the fraternity becomes more intensive. Thus, each group tried to prevent conflicts which can occur to maintain the harmonious relation. With the use of capital game played by the two ethics to win the contests in the effort to maintain the position of each group causes them to make their best to make a balance between both of them so that the condition became balanced and this was the starting point in developing a harmonious life.

The statement above parallels to what Mr. Made Sukarya (65) who happened to have a Chinese ethnic descendent wife, who said that:

"Since I married Cik Etjap (his late wife) the relation with my wife's family has developed quite well. Similarly, every time there was a joy and sad event the people from my wife's family always come amidst the family who holds the feast or ritual and the reverse is also true".

The quote from the interviewee indicated that the social capital and symbolic game between the Balinese family and the Chinese family to maintain a harmonious relation by paying a visit to each other and by helping each other when there is a feast both in happiness and sorrow to make their relation closer with each other (penyamabrayaan). Consequently, they try to prevent misunderstanding which can cause a rift in their relation. Hence, all parties tried to control themselves to maintain a good relation to actualize a harmonious life although they came from different ethnics.
The development of the feeling of being on the same boat due to the historical experience of the two ethnics in Pupuan village encouraged the agreement to live side by side in peace (harmony) and to commit themselves to develop the village together, since Pupuan is regarded by them as their land of birth and their belonging. Similarly, the external party's role, both the central government and the local government cannot be ignored, since they have interest in developing peace (harmony) in the society so that some regulations were issued such as Local Government Regulation No. 3/2001 on Desa Pakraman with the hope that social law and order (harmony) can be developed in the society. Education also has an important role to create the harmonious in this village [29]. It was proved by the tolerance among the students who have different ethnics and they can work together and also respecting each other.

\section{CONCLUSION AND SUGGESTION}

In the light of the study that was conducted there were conclusions which can be made and some findings found. The development of the harmonious relation between Chinese ethnics and Balinese in Pupuan village was caused by interests, power and capital game played by both ethnics, the prioritizing of tolerance, mutual respect, and equality in diversity. Thus, the community of Pupuan village can actualize the motto Bhinneka Tunggal Ika (unity in diversity) and multiculturalist's doctrine in their social life. So, the harmonious life in Pupuan village, Tabanan, Bali between Chinese and Balinese ethnics can be actualized due to the presence of positive or productive power game as stated in Foucault's power/knowledge discourse theory.

\section{Suggestions}

There are several suggestions that can be used as a consideration for those who are concerned with social phenomenon in the community, as follows: (1) The research needs to be followed up for its completeness considering the limitation of the researcher in various matters by taking some extension on research location to the existence of the Chinese ethnic so it can enrich the study on ethnics as an interesting topic in cultural study; (2) The stakeholder should continuously conducting the supervision to maintain the harmonious life among community members or inter-ethnics in pluralistic and multicultural society so unity in nation and state can be realized in facing globalization era recently; (3) The teachers also hoped to create a harmonious live among the different students who have different ethnics by teaching them to tolerance and respecting the differences among them and also create the sense of belonging between the

\section{REFERENCES}

[1] Pupuan Village Monograph, 2015 
[2] Vasanty, Puspa. 1987. "Kebudayaan Orang Tionghoa Indonesia", dalam Koentjaraningrat, ed. Manusia dan Kebudayaan di Indonesia. Jakarta: Djambatan

[3] Purdey, Jemma.2006. Kekerasan Anti Tionghoa di Indonesia 19961999. Denpasar:Pustaka Larasan

[4] Habib, Achmad. 2004. Konflik Antaretnik di Pedesaan: Pasang Surut Hubungan Cina-Jawa. Yogyakarta: LKiS

[5] Habib, Achmad. 2004. Konflik Antaretnik di Pedesaan: Pasang Surut Hubungan Cina-Jawa. Yogyakarta: LKiS

[6] Geriya, I Wayan. 2008. "Pola Hubungan Antaretnis Bali dan Tionghoa dalam Dinamika Kebudayaan dan Peradaban" dalam Integrasi Budaya Tionghoa ke Dalam Budaya Bali (Sebuah Bunga Rampai), Sulistyawati (ed.). Denpasar: Universitas Udayana Bali

[7] Beratha, Ni Luh Sutjiati, Ardika dan Dhana. 2010. Dari Tatapan Mata ke Pelaminan sampai di Desa Pakraman: Studi tentangHubungan Orang Bali denganorang Cina di Bali Denpasar:Udayana University Press

[8] Coppel, Charles A. 1994. Tionghoa Indonesia Dalam Krisis.Jakarta: Pustaka Sinar Harapan

[9] Poerwanto, Hari. 2005. Orang Cina Khek dari Singkawang. Depok: Komunitas Bambu

[10] Purdey, Jemma.2006. Kekerasan Anti Tionghoa di Indonesia 19961999. Denpasar:Pustaka LarasanFoucault, Michel.1980. Power/Knowledge. New York: Pantheon

[11] Suryadinata, Leo. 1986. Politik Tionghoa Peranakan di Jawa. Jakarta: Sinar Harapan

[12] Suryadinata, Leo.1988. Kebudayan Minoritas Tionghoa di Indonesia (Dede Oetomo,penterj.) Jakarta: PT. Gramedia

[13] Suryadinata, Leo.1999. Etnis Tionghoa dan Pembangunan Bangsa.Jakarta: LP3ES.

[14] Suryadinata, Leo.2002. Negara dan Etnis Tionghoa: Kasus Indonesia.Jakarta: LP3ES

[15] Hadi, Syamsul. 2009. Hubungan Indonesia Cina di Era Pasca Orde Baru: Perspektif Indonesia dalam Merangkul Cina Hubungan
Indonesia Cina Pasca Orde Baru. Jakarta: PT.Gramedia Pustaka Utama

[16] Wirata, I Ketut. 2000. "Integrasi Etnis Tionghoa di Desa Adat Carangsari, Kecamatan Petang, Kabupaten Badung" Tesis Magister (S2) Program Kajian Budaya Program Pascasarjana Universitas Udayana

[17] Yudha, I Putu Putra Kusuma. 2014. "Perubahan Identitas Budaya Etnis Tionghoa di Desa Pupuan Kecamatan Pupuan Kabupaten Tabanan", Tesis S-2 Pascasarjana Program Studi Kajian Budaya Universitas Udayana

[18] Spradley, James P. 2006. Metode Etnografi. Yogyakarta: Tiara Wacana

[19] Habermas, Jurgen. 1971. Knowledge and Human Interest. Boston: Beacon

[20] Bourdieu, Pierre. 1984. Homo Academicus, Traslated by Peter Collier. California: Stanford Univ

[21] Bourdieu, Pierre.1986. The Forms of Capital, In: Richardson J.G.(ed.) Handbook of Theory and Research of the Sociology of Education, pp.241-258. New York:Greenwood Press

[22] Bourdieu, Pierre.1990. The Logic of Practice.Palo Alto. Stanford University Press

[23] Bourdieu, Pierre.1991.Languageand Symbolic Power. (Gino Raymond, Penerj.) Cambridge: Polity Press

[24] Bourdieu, Pierre.1992. An Invitation to Reflexive Sociology. Chicago: The University of Chicago Press

[25] Foucault, Michel.1980. Power/Knowledge. New York: Pantheon

[26] Foucault, Michel.1997. Disiplin Tubuh, Bengkel Individu Modern. Yogyakarta: LK

[27] Habermas, Jurgen. 1971. Knowledge and Human Interest. Boston: Beacon

[28] Gramsci, Antonio. 1968. Prison Notebooks. London: Lawrence and Wishart

[29] Surpha, I Wayan.2012. Seputar Desa Pakaraman dan Adat Bali. Denpasar: Pustaka Bali Post 